НАУКОВІ ПІДХОДИ ДО СТАНОВЛЕННЯ ПРОФЕСІЙНОЇ УСПІШНОСТІ МАЙБУТНІХ УЧИТЕЛІВ НОВОЇ УКРАЇНСЬКОЇ ШКОЛИ

\title{
SCIENTIFIC APPROACHES TO THE FORMATION OF PROFESSIONAL SUCCESS OF FUTURE TEACHERS OF THE NEW UKRAINIAN SCHOOL
}

Вітчизняні та зарубіжні науковці намагаються трактувати професійну успішність вчителя як прочес і результат профресійної діяльності, що характеризується стійкою спрямованістю на профресійний саморозвиток та професійні досягнення. Характеризуючи методологічні підходи дослідження профресійної успішності майбутніх вчителів закладів загальної середньої освіти, науковці доводять існування різних аспектів та складових успішності особистості у профресійній діяльності.

мета статmі - визначити роль наукових підходів до процесу становлення професійної успішності як учителів, так і майбутніх учителів Нової української школи. Для реалізації мети дослідження використано наступні теоретичні та емпіричні методи: теоретичний аналіз, порівняння та зіставлення - для визначення процесу становлення професійної успішності як учителів, так і майбутніх учителів Нової української школи.

Для вивчення процесу становлення професійної успішності теоретичні засади системного підходу дають змогу досить ґрунтовно висвітлити процес управління власними емоціями та емоціями інших; здатність до рефллексії та ефективноі міжособистісної комунікації, що забезпечує успішну соціальну адаптацію людини. Провідними науковими підходами до процесу становлення професійної успішності вчителів для статmі $\epsilon$ системний та суб'єктний. Системний підхід характери зує педагогічну систему, визначає ї межі, структурні компоненти, їхні взаємозв'язки, особливості взаємодії та фрункціонування. Висновки. Останнім часом теорія і практика профресійної освіти дає змогу стверджувати, що можна виокремити основні ознаки майбутнього вчителя Нової української школи як суб'єкта профресійної успішності: здобувач вищої освіти усвідомлює себе як майбутнього вчителя, який має бути успішним та конкурентоспроможним, а тому вмотивований до набуття та розвитку професійних компетентностей; відповідальний за свої майбутні профресійні досягнення, а тому вмотивований на безперервне професійне удосконалення та саморозвиток задля вирішення особистісних, суспільних та профресійних завдань.

Ключові слова: учителі, Нова українська школа, професійна успішність вчителів, наукові підходи.
Domestic and foreign scholars try to interpret the professional success of teachers as a process and result of professional activity, characterized by a stable focus on professional self-development and professional achievements. Characterizing the methodological approaches to the study of professional success of future teachers of general secondary education, scientists prove the existence of various aspects and components of personal success in professional activities.

The purpose of the article is to determine the role of scientific approaches to the process of formation of professional success of both teachers and future teachers of the New Ukrainian School.

To achieve the purpose of our study, the following theoretical and empirical methods were used: theoretical analysis, comparison and comparison - to determine the process of formation of professional success of both teachers and future teachers of the New Ukrainian School.

To study the process of formation of professional success, the theoretical foundations of a systematic approach allow you to thoroughly cover the process of managing their own emotions and the emotions of others; ability to reflect and effective interpersonal communication, which ensures successful social adaptation.

The leading scientific approaches to the process of formation of professional success of teachers for our article are: systemic and subjective. The system approach characterizes the pedagogical system, determines its boundaries, structural components, their relationships, features of interaction and functioning.

Conclusions. Recently, the theory and practice of vocational education suggests that we can identify the main features of the future teacher of the New Ukrainian School as a subject of professional success: the higher education seeker as a future teacher who must be successful and competitive, and therefore motivated to acquire and develop professional competencies; responsible for their future professional achievements, and therefore motivated for continuous professional development and self-development to solve personal, social and professional problems.

Key words: teachers, New Ukrainian school, professional success of teachers, scientific approaches.
Постановка проблеми в загальному вигляді. Характеризуючи методологічні підходи дослідження професійної успішності майбутніх вчителів закладів загальної середньої освіти, науковці доводять існування різних аспектів та складових успішності особистості у профеесійній діяльності, що $є$ досить актуальними у психолого-педагогіч- них дослідженнях. Вітчизняні та зарубіжні науковці намагаються трактувати професійну успішність вчителя як процес і результат профресійної діяльності, що характеризується стійкою спрямованістю на професійний саморозвиток та профресійні досягнення, цілепокладанням та ціледосягненням, що має позитивну зовнішню та внутрішню оцінку. 
Аналіз останніх досліджень і публікацій. Проблемі різних аспектів професійної успішності сучасних учителів Нової української школи присвячені дослідження як зарубіжних, так і вітчизняних вчених, серед них - П. Гонди, Н. Дюшеєва, М. Євтух, Я. Каплуненко, О. Осницький, О. Отич, К. Скай, М. Квсйхаген, Т. Скорик та інші. Вони акцентували на профресійній успішності, загальнонаукових та конкретно-наукових методологічних підходах до цієї проблеми, їхні дослідження визначалися відповідно до міждисциплінарного, комплексного характеру профеесійної успішності вчителя.

Виділення не вирішених раніше частин загальної проблеми. Проте невирішеним залишається процес становлення профресійної успішності як учителів-практиків, так і майбутніх учителів Нової української школи.

Мета статті - визначити роль наукових підходів до процесу становлення профресійної успішності як учителів-практиків, так і майбутніх учителів Нової української школи.

Виклад основного матеріалу дослідження. Центральне місце в дослідження посідає характеристика висвітлення ролі деяких наукових підходів до процесу становлення професійної успішності як учителів-практиків, так і майбутніх учителів Нової української школи.

Маємо погодитися 3 думкою вітчизняного науковця О. Отич, що «в сучасній педагогічній науці, поряд із традиційними методологічними підходами, [...] все вагоміше місце посідають нові методологічні підходи (полісуб'єктний, креативний, медіологічний, семіотичний, герменевтичний, френоменологічний, цивілізаційний, холістичний), які, на погляд ученої, більше узгоджуються із сучасними соціальними та освітніми реаліями» [8, с. 41]. Констатуємо, що процес формування профеесійної успішності майбутніх учителів буде ґрунтуватися на кількох взаємопов'язаних наукових підходах, з-поміж яких виокремлюємо: загальнонаукові - системний, синергетичний, історико-цивілізаційний, конкретно-наукові діяльнісно-орієнтовані (діяльнісний, праксеологічний), особистісно-орієнтовані (гуманістичний, антропологічний, культурологічний, аксіологічний, суб'єктний) та профресійно-орієнтовані (професіографічний, акмеологічний). Провідними для нашого дослідження виокремлюємо вісім: системний; синергетичний; праксеологічний; аксіологічний; компетентнісний; акмеологічний; суб'єктний; х'ютагогічний.

Вважаємо за потрібне наголосити на твердженні видатного вітчизняного вченого С. Гончаренка, що «у плануванні та проведенні педагогічного дослідження необхідно орієнтуватися на методологічні принципи й конкретно-наукові форми їх прояву згідно з теоретичною позицією дослідника» [2, с. 84]. Спираючись на його дослід- ження, маємо констатувати, що «методологію розуміють як загальну систему теоретичних знань, що виконують роль провідних принципів наукового пізнання, шляхів і засобів реалізації наукового дослідження». Особливість методологічних принципів полягає у визначенні вихідних наукових позицій [2, с. 88]. Вчений також вважав, що теоретико-методологічна основа розкривається для вказівки на орієнтацію дослідження на той чи інший підхід у науці для розв'язання проблем цієї предметної галузі.

Зарубіжна дослідниця Н. Дюшеєва та вітчизняна вчена Т. Скорик також визначають, що методологічний підхід - «стратегія, що базується на основних положеннях відповідної теорії та визначає напрями пошуку стосовно предмета дослідження» [4, с. $19 ; 10$, с. 118]. Аналіз наукових праць як вітчизняних, так і зарубіжних вчених дає змогу зробити висновок про відсутність єдиного методологічного підходу до визначення поняття «професійна успішність», а більшість дослідників визначає професійну успішність як «метакатегорію», що має різні підходи до тлумачення та визначення. Різноплановість тлумачень свідчить про комплексність підходів до дослідження цього конструкту. 3 фрілософрської точки зору явище профресійної успішності вказує на важливість співвідношення у ньому загального і одиничного, діалектики особливого, необхідного і випадкового.

Досліджуючи системний підхід, спираємося на праці вітчизняної вченої Т. Скорик, яка вважає, що «одним із провідних у педагогічній науці й освітній практиці $є$ системний підхід, який базується на теорії систем. Його сутність полягає в аналізі об'єкту як цілісної системи, як множини елементів у сукупності відношень і зв'язків між ними». Системний підхід характеризує педагогічну систему, визначає ії межі, структурні компоненти, їхні взаємозв'язки, особливості взаємодії та фуункціонування, чинники моніторингу та прогнозування результатів навчання і виховання, визначення напрямів управління системою [10, с. 119].

Для вивчення процесу становлення професійної успішності теоретичні засади системного підходу дозволяють досить ґрунтовно висвітлити процес управління власними емоціями та емоціями інших; здатність до ресрлексії та ефрективної міжособистісної комунікації, що забезпечує успішну соціальну адаптацію людини.

Дослідження вітчизняного вченого Я. Каплуненко у дисертаційній роботі «Особистісні чинники розвитку соціального інтелекту у фрахівців соціономічних професій» фрормулюють узагальнене визначення соціального інтелекту: «соціальний інтелект - це інтегральна соціально-особистісна пізнавальна здібність людини, яка забезпечує успішність соціальної адаптації та ефективність міжособистісної взаємодії та включає здатність до 
пізнання поведінки і комплексного аналізу ситуацій спілкування; здатність до розуміння й управління власними емоціями та емоціями інших; здатність до здійснення організаційно-комунікативної діяльності». Маємо зазначити, що соціальний інтелект дасть змогу більш глибоко оволодіти процесом становлення профресійної успішності майбутнього вчителя Нової української школи [6, с. 8].

У дослідженнях зарубіжних авторів К. Ская, П. Гонди і М. Квсйхагена [12] також досліджується соціальний інтелект. Проте вчені вважають, що соціальний інтелект у зв'язку 3 парадигмальним аналізом «життєвої компетентності», що «передбачає набуття людиною вмінь виробляти стратегії діяльності, планувати перспективні дії, яких має досягнути суб'єкт у результаті чітко сорормульованої мети», має потребу вмінь для вироблення висновків з огляду на успіхи або невдачі підчас складання майбутніх планів [12, с. 67].

На думку науковців, соціальний інтелект фасилітує становлення в індивіда вміння використовувати когнітивні стратегії виконання діяльності в повсякденних життєвих ситуаціях та ситуаціях профресійної взаємодії. Згідно 3 визначенням К. Скай, «соціальний інтелект - це фенотипічне поєднання генотипічно маркованих фракторів інтелектуального розвитку, що забезпечує ефективність адаптивної поведінки людини у специфічних ситуаціях соціальної взаємодії». Про це важливо пам'ятати в процесі нашого дослідження становлення професійної успішності [12, с. 84].

Одним із важливих підходів необхідно вважати педагогічну мотивацію (свідомий умотивований вибір профресії), до якої уналежнюємо: гуманістичну спрямованість (любов до дітей, повага, толерантність); особистісні якості (чесність, справедливість, чемність, вимогливість, цілеспрямованість, працездатність, наполегливість) та зовнішні чинники (безпечне освітнє середовище, співпраця і підтримка педагогічного колективу).

Акмеологічний підхід до становлення професійної успішності як учителів-практиків, так і здобувачів вищої освіти, майбутніх учителів Нової української школи впливає на всі аспекти життєдіяльності вчителя, змінює мотиви, потреби, ціннісні установки на людиноцентровані, визначає гуманістичну спрямованість особистості. Проте «акмеологічна спрямованість вчителя на постійний саморозвиток і самовдосконалення є джерелом підтримки сталості професійної успішності впродовж усього профресійного шляху, визначає високу продуктивність та емоційну комфрортність у професійній діяльності» [5, с. 12-13].

Важливим єй суб'єктний підхіддо процесу становлення профресійної успішності майбутнього вчителя. щодо суб'єктного підходу, то в нашому дослідження суб'єктного (суб'єкт-суб'єктного) підходу спираємося на його обґрунтування у роботах зарубіжного вченого О. Осницького [7, с. 317]. У більшості психолого-педагогічних досліджень теоретико-методологічного спрямування прослідковується положення щодо підготовки майбутнього вчителя як суб'єкта пізнавальної діяльності у закладах вищої освіти, а «навчально-профресійної - у процесі педагогічних практик, який є здатним цілеспрямовано регулювати свій професійний розвиток» [9, с. 8]. У рамках нашого дослідження вважаємо, що здобувач вищої педагогічної освіти у процесі навчання та майбутньої профресійної діяльності «стає суб'єктом педагогічної взаємодії, переносячи досвід взаємодії з освітніх ситуацій на профресійні» [10, с. 143]. Отже, у процесі профресійної підготовки фрормується суб'єктне ставлення до життя та профресії майбутнього вчителя Нової української школи.

Як слушно зауважує зарубіжний вчений О. Осницький, суб'єктне ставлення до життєдіяльності «відбувається шляхом звернення людини до своїх внутрішніх резервів, вибору засобів діяльності на основі взаємодії сорормованих навичок саморегуляції та компонентів суб'єктного досвіду». Суб'єктний досвід передбачає усвідомлення можливостей, правил організації дій, значущих цінностей, ієрархію вподобань, бажань людини та створює можливості для постановки власних завдань, для вибору відповідного значущого для неї завдання із завдань, що нав'язуються ззовні [7, с. 316]. Дослідник наголошує на існуванні п'яти компонентів суб'єктного досвіду, що взаємодіють один $з$ одним: «ціннісний досвід (інтереси, моральні норми, вподобання, ідеали, переконання), досвід рефрлексії (знання про свої можливості та можливі перетворення в предметному середовищі і в собі); досвід звичної активації (попередня підготовленість, оперативна адаптивність до мінливих умов роботи, розрахунок на певні зусилля і рівень досягнення успіху); раціональний досвід (знання і вміння, навички саморегуляції)». Разом із вітчизняною вченою Т. Скорик маємо наголосити, що всі означені компоненти «реалізуються в погребовій, діяльнісний, міжособистісній сорерах, у переживаннях, у свідомості людини - у сфері потягів, інтересів, можливості, а їхня взаємодія забезпечує активні, цілеспрямовані, усвідомлені й скоординовані з іншими дії щодо вирішення творчих завдань саморозвитку» [10, с. 144].

Маємо наголосити, що дослідження багатьох вітчизняних та зарубіжних вчених доводять думку про те, що суб'єкт-суб'єктний підхід до професійної успішності вчителя вказує на активність, цілеспрямованість вчителя у напрямі вдосконалення власних професійних дій та досягнення їхньої ефективності. Погоджуємось із думкою В. Слободчикова, який стверджує, що «здатність особистості організувати і регулювати своє життя як підпорядкування власним цілям, цінностям є вищим рівнем і справжньою якістю суб'єкта» [11]. 
Есрективність становлення професійної успішності майбутнього вчителя безпосередньо залежить від того, які відносини склалися в освітньому процесі (здобувач вищої освіти-викладач, здобувач вищої освіти-здобувач вищої освіти, практикант-здобувачі загальної середньої освіти, практикант-колектив закладу загальної середньої освіти). Здобувача вищої освіти маємо розглядати як «суб'єкта» освітнього процесу - «носія цілей і технологій їхньої реалізації, завдяки яким відбувається його становлення як «суб'єкта» самонавчання, самовиховання й управління взаємодією 3 навколишнім світом» [3, с. 8].

Суб'єкт-суб'єктні відносини є важливою складовою міжособистісної педагогічної взаємодії, що реалізує базову потребу особистості в залученні ії до соціуму і культури суспільства на основі рівноправного партнерства 3 учителем, характеризує готовність суб'єктів виховання до взаєморозуміння та взаємоповаги у процесі спілкування і діяльності; «суб'єкт-суб'єктний характер відносин між учителем і здобувачем загальної середньої освіти є запорукою збереження індивідуальності особистості, ії унікальності, різнорівневості й різноплановості у здібностях, можливостях, інтересах, погребах» [1, с. 383-384].

Маємо констатувати, що суб'єкт-суб'єктна взаємодія $€$ однією з найбільш важливих характеристик освітнього процесу, що передбачає безпосередній чи опосередкований валив суб'єктів один на одного, що стимулює взаємозумовлений їхній зв'язок у контексті спілкування.

Погоджуємося 3 твердженням Т. Скорик, що здобувач вищої педагогічної освіти «має виступати не як пасивний об'єкт педагогічного управління і простий накопичувач знань, але насамперед як суб'єкт пізнавальної діяльності», який своєю активністю значною мірою визначає результати освітньої діяльності [10, с. 145].

Отже, суб'єктно-професійна позиція майбутнього вчителя сприятиме виявленню творчого потенціалу, ресрлексії, відповідальності, активності, дозволить інтенсифрікувати індивідуальний ресурс, що забезпечить як можливість успішного освоєння професії, так і становлення профресійної успішності у подальшій професійній діяльності.

Висновки. Останнім часом теорія і практика професійної освіти дозволяє стверджувати, що можна виокремити основні ознаки майбутнього вчителя Нової української школи як суб'єкта профресійної успішності: здобувач вищої освіти усвідомлює себе як майбутнього учителя, який має бути успішним та конкурентоспроможним, а тому вмотивований до набуття та розвитку професійних компетентностей; відповідальний за свої майбутні профресійні досягнення, а тому вмотивований на безперервне професійне удосконалення та саморозвиток задля вирішення особистісних, суспільних та професійних завдань.

Перспективами подальших наукових розвідок цього напряму вважаємо дослідження х'ютагогічного підходу до вивчення професійної успішності майбутніх учителів, що визначається як сучасне вчення про безперервну освіту як стиль життя, про самоосвіту як провідну фоорму освіти, що поєднує кращі інноваційні практики в організації самоосвіти.

\section{БІБЛІОГРАФІЧНИЙ СПИСОК:}

1. Андреева И.Н. Эмоциональный интеллект как феномен современной психологии. Новополоцк : ПГУ, 2011. 388 с.

2. Гончаренко С.У. Педагогічні дослідження: Методологічні поради молодим науковцям. Київ Вінниця : ДОВ «Вінниця», 2008. 278 с.

3. Дворянкина Е.К. Моделирование образовательной системы вуза по развитию студентов как субъектов профессионально-педагогической деятельности: авторефр. дис. ... докт. пед. наук : 13.00.08. Хабаровск, 2012. 32 с

4. Дюшеева Н.К. Методологические подходы к профессионально-личностному фрормированию будущего учителя. Педагогическое образование и наука. 2008. № 9. С. 16-23.

5. Євтух М.Б., Скорик Т.В. Акмеологічний підхід до становлення професій успішності майбутнього вчителя. Вісник Національного університету «Чернігівський колегіум» імені Т. Г. Шевченка. 2020. Вип. 7(163). С. 8-13.

6. Каплуненко Я.Ю. Особистісні чинники розвитку соціального інтелекту у фрахівців соціономічних професій : автореф. дис. ... канд. психол. наук : 19.00.01. Київ, 2016. 24 с.

7. 7. Осницкий А.К. Деятельностное и личностное в проявлениях субъекта. Субъектный подход в психологии. Москва : Изд-во Ин-та психологи РАН, 2009. C. 314-324.

8. Отич О.М. Методологічні принципи наукового дослідження. Вісник Чернігівського державного педагогічного університету. Серія: Педагогічні науки. 2010. Вип. 76. С. 41-43.

9. Пехота О.М., Кіктєнко А.3., Любарська О.М. та ін. Освітні технології : навч.-метод, посіб. / за заг. ред. О.М. Пєхоти. Київ : А.С.К., 2004. 256 с.

10. Скорик Т.В. Розвиток професійної успішності майбутнього вчителя в закладах вищої освіти України (друга половина XX - початок XXI століття) : монографія. Черкаси : Видавець Чабаненко Ю.А., 2020. 314 с.

11. Словник української мови. Академічний тлумачний словник (1970-1980). URL: http://sum.in.Ua/s/ peredumovaa (дата звернення: 24.09.2021).

12. Guilford J. The nature of human intelligence. New York : McGraw Hill, 1967. 538 p. 